\title{
Seed Treatment with Trichoderma harzianum Alleviates Biotic, Abiotic, and Physiological Stresses in Germinating Seeds and Seedlings
}

\author{
Fatemeh Mastouri, Thomas Björkman, Gary E. Harman
}

Department of Horticultural Sciences, Cornell University, Geneva, NY 14456.

Accepted for publication 8 July 2010.

\begin{abstract}
Mastouri, F., Björkman, T., and Harman, G. E. 2010. Seed treatment with Trichoderma harzianum alleviates biotic, abiotic, and physiological stresses in germinating seeds and seedlings. Phytopathology 100:12131221.

Trichoderma spp. are endophytic plant symbionts that are widely used as seed treatments to control diseases and to enhance plant growth and yield. Although some recent work has been published on their abilities to alleviate abiotic stresses, specific knowledge of mechanisms, abilities to control multiple plant stress factors, their effects on seed and seedlings is lacking. We examined the effects of seed treatment with T. harzianum strain T22 on germination of seed exposed to biotic stress (seed and seedling disease caused by Pythium ultimum) and abiotic stresses (osmotic, salinity, chilling, or heat stress). We also evaluated the ability of the beneficial fungus to overcome physiological stress (poor seed quality

more uniformly than untreated seeds whether the stress was osmotic, salt, or suboptimal temperatures. The consistent response to varying stresses suggests a common mechanism through which the plant-fungus association enhances tolerance to a wide range of abiotic stresses as well as biotic stress. A common factor that negatively affects plants under these stress conditions is accumulation of toxic reactive oxygen species (ROS), and we tested the hypothesis that T22 reduced damages resulting from accumulation of ROS in stressed plants. Treatment of seeds reduced accumulation of lipid peroxides in seedlings under osmotic stress or in aged seeds. In addition, we showed that the effect of exogenous application of an antioxidant, glutathione, or application of T22, resulted in a similar positive effect on seed germination under osmotic stress or in aged seed. This evidence supports the model that $T$. harzianum strain T22 increases seedling vigor and ameliorates stress by inducing physiological protection in plants against oxidative damage.
\end{abstract} induced by seed aging). If seed were not under any of the stresses noted above, T22 generally had little effect upon seedling performance. However, under stress, treated seed germinated consistently faster and
Additional keywords: seedling growth.

These fungi are frequently applied as seed treatments, where they may improve plant stands and induce long-term improvements in plant quality $(28,29)$. Therefore, seed treatments can induce both short-term and long-term improvements in seed and subsequent plant performance; however, very little is known about the early seed-Trichoderma spp. interactions. These interactions are important because (i) they can provide insights into long-term plant performance and (ii) seed-Trichoderma spp. interactions, if properly characterized and quantified, can provide powerful and rapid systems to examine mechanisms and physiological processes of the plant-Trichoderma spp. interactions. We created a series of hypotheses to test in this study in order to better understand the nature of the effect that Trichoderma spp. have on tolerance to abiotic stresses, as follows.

(i) Seed respond positively to treatment with Trichoderma harzianum when exposed to physiological, biotic, or abiotic stresses but the beneficial fungus has little or no effect on seed not exposed to these stresses.

(ii) Treatment of seed with $T$. harzianum ameliorates a wide variety of biotic, abiotic, and physiological stresses to seed and seedlings. As far as we are aware, there has been no other systemic study focusing on the abilities of this fungus to improve seedling or growing plant performance across a variety of stressful conditions. Instead, other studies have focused on only one stress factor at a time and, due to the differences in the experimental conditions, including differences in plant species or fungal species, comparisons are hard to make.

(iii) Seed respond to T. harzianum very early in germination (i.e., before radicle protrusion). As mentioned, the prevailing 
hypotheses in this area revolve around the enhanced root growth or plant enhanced water-holding capacity due to Trichoderma treatment; however, if seed germination under stress is enhanced, an alternative explanation is required.

The goals of this study were to evaluate the ability of $T$. harzianum to improve germination and seedling performance in (i) good-quality seeds in the absence of stress and (ii) with stresses imposed by seed aging (physiological stress) or unfavorable osmotic stress, salinity, or temperature conditions as well as biotic stress (attack by the seed and seedling pathogen Pythium ultimum); and (iii) to determine whether amelioration of toxic effects of reactive oxygen species (ROS) may be involved in beneficial effects of the beneficial fungus on seed under stress.

\section{MATERIALS AND METHODS}

Plant material and seed aging. Seed of tomato (Lycopersicum esculentum L.) cv. Jubilee (Harris Seeds, Rochester, NY) were used in this study. To produce seed with reduced quality, seed were artificially aged (14,22). Briefly, seeds that were equilibrated to $70 \%$ relative humidity were incubated for various periods $\left(0,10\right.$, and 20 days) at $38^{\circ} \mathrm{C}$ in sealed aluminum pouches.

Fungal isolate. T. harzianum Rifai strain T-22 (American Type Culture Collection no. 20847) was used for this study. This strain is rhizosphere competent, capable of inducing systemic resistance and stimulating plant growth $(11,29,35,58)$. It has been shown to induce systemic changes in the transcriptome and proteome of maize $(34,58,60,68)$, even though it colonizes only few layers of root cortex and epidermis (68). To prepare seed treatment inoculants, conidia were coated onto cellulose and encapsulated with tapioca dextran (Crystal-Tex, National Starch, NJ). A suspension of conidia in sterile type I water was prepared for seed treatment. Seed were treated with the conidial suspension at the rate of $20 \mu \mathrm{g} \mathrm{g}^{-1}$ to deposit $2 \times 10^{7} \mathrm{CFU} \mathrm{g} \mathrm{g}^{-1}$ of seed. Control seed were treated with an equal amount of type I sterilized water. Treated seed were used for planting without air drying.

Sporangia of Pythium ultimum were produced according to Taylor et al. $(23,36,62)$ and the level of inoculant was adjusted to a level that caused $25 \%$ mortality.

Seed germination test and seedling growth. In vitro condition. Seed were germinated in clear plastic boxes ( 12 by 12 by $5 \mathrm{~cm}$ ) with lids. In all, 100 seeds of each treatment (unaged or aged seed of tomato treated with T22 or untreated) were placed on two layers of blotter papers moistened with $16 \mathrm{ml}$ of sterile type I water for each replicate. Each experiment included four replicates and was repeated at least twice. Boxes were incubated at $25 \pm 1{ }^{\circ} \mathrm{C}$ with $16 \mathrm{~h}$ of light. Germination was measured every $12 \mathrm{~h}$ and seeds counted as germinated when the radicle protruded through the seed coat. The percentage of normal seedlings as defined in standard germination testing (4) was measured 14 days after imbibition. Time to germination of $50 \%$ of seed $\left(\mathrm{T}_{50}\right)$ was used as an indicator of average speed of germination (22) and as a sensitive measure of seed vigor.

To quantify the effect of T22 treatment on plant growth and fitness in vitro, unaged or rapidly aged seed treated or untreated with T22 were planted in sterilized Magenta boxes half filled with $0.8 \%$ water agar. Twenty-five seeds of each treatment were planted in each box and incubated at $25 \pm 1^{\circ} \mathrm{C}$ with $16 \mathrm{~h}$ of light of $\approx 180 \mu \mathrm{mol} \mathrm{m} \mathrm{m}^{-2} \mathrm{~s}^{-1}$. Seedlings were harvested 14 days after planting (DAP). Radicle and hypocotyl fresh weight (FW) and length were measured as indications of seedling vigor. The radicles or hypocotyls of normal seedlings from each replicate were pooled and dried at $65^{\circ} \mathrm{C}$ for $48 \mathrm{~h}$. Average dry weight (DW) was calculated as a pool of radicles or hypocotyls in each replicate divided by the number of normal seedlings in that unit.

Germination in Pythium spp.-infested soil. To compare the effect of $T$. harzianum on germination in presence or absence of diseases, seedling emergence was also studied in soil infested with Pythium ultimum strain $\mathrm{P}_{4}$. Small, transparent boxes (15 by 15 by $5 \mathrm{~cm}$ ) were filled with either autoclaved Arkport sandy loam (as a control) or Pythium spp.-infested sandy loam (infested soil). Twenty unaged seeds of Jubilee tomato, either treated with T22 or not treated, were planted in each box as a replicate. Each treatment was replicated eight times. Boxes were incubated in a growth chamber with $16 \mathrm{~h}$ of light at $25 \pm 1^{\circ} \mathrm{C}$. Seedling emergence was measured every $24 \mathrm{~h}$ and seedlings that showed symptoms of damping off or were dead were counted. Plants were harvested at 14 DAP, when FW and length of radicles and hypocotyls were determined. Average DW for each replicate was determined.

Effect of Trichoderma treatment on germination under abiotic stresses. Osmotic stress. Seed of Jubilee tomato, treated with T22 or untreated, were planted in $0.8 \%$ water agar $(0.15 \%$ [wt/vol] Difco agar) plates (control). Polyethylene glycol (PEG) (MW 8000; Sigma-Aldrich, St Louis) was added at 9.8, 13.8, and $16.9 \%$ ( $\mathrm{P} 1, \mathrm{P} 2$, and $\mathrm{P} 3$, respectively) to lower water potential to $-0.1,-0.2$, and $-0.3 \mathrm{MPa}$. Five replications of 100 seeds were planted. Seed were incubated at $25 \pm 1{ }^{\circ} \mathrm{C}$ with $16 \mathrm{~h}$ of light and germination was measured every $24 \mathrm{~h}$ for up to 14 days to determine $\mathrm{T}_{50}$. The percentage of normal seedlings was determined after 14 days according to the AOSA guidelines (4). Radicle and hypocotyl FW and length were determined and then the average DW of radicles and hypocotyls of each replicate was determined.

Salinity stress. Seed of Jubilee tomato, treated with T22 or untreated, were planted in $0.8 \%$ (wt/vol) water agar with 0,50 , 100 , or $150 \mathrm{mM} \mathrm{NaCl}$ (control, S1, S2, or S3, respectively). Seed germination tests were carried out as for osmotic stress and $\mathrm{T}_{50}$, percentage of normal seedlings, radicle and hypocotyl FW, and average DW of radicles and hypocotyls were determined.

Chilling or heat stress. To expose seed to chilling or heat stress during germination, unaged seed of tomato cv. Jubilee, treated with T22 or untreated, were placed on blotter paper moistened with $16 \mathrm{ml}$ of type I water following the procedure described above, except that, after $24 \mathrm{~h}$ after the start of imbibition, seed were transferred to either $10 \pm 0.2^{\circ} \mathrm{C}$ (chilling stress) or $35 \pm$ $0.5^{\circ} \mathrm{C}$ (heat stress) for 24 or $72 \mathrm{~h}$. After exposure to these temperatures, seed were returned to the germination chambers. Germination was measured every $12 \mathrm{~h}$ and each treatment was allowed to germinate and grow for up to 14 days in a germination chamber. Seedling growth, radicle and hypocotyl FW, and average DW were measured after 14 days.

Measurement of lipid peroxides. Lipid peroxidation is commonly used as an indicator of oxidative damage. We measured lipid peroxides in tomato seedlings grown in the presence or absence of the osmotic stress or seed aging. The two stresses were chosen because they represent independent sources of stress to the germinating seed. To obtain samples of comparable physiological age, all seedlings with radicles measuring $3 \mathrm{~mm}$ or longer were harvested when $\approx 50 \%$ germination was achieved. Total lipids was extracted following Hara and Radin (25), with modifications. Briefly, $0.5 \mathrm{~g}$ of plant sample, ground in liquid nitrogen, was mixed with $7 \mathrm{ml}$ of hexane/isopropanol (3:2) and centrifuged for $10 \mathrm{~min}$ at 5,000 rpm. The supernatant was collected and the pellet was centrifuged again with an additional $2 \mathrm{ml}$ of extraction media. Supernatant from two steps was combined and lipid peroxides were determined using colorimetric assay with the PeroxiDetect kit (Sigma-Aldrich) according to the manufacturer's direction.

Exogenous application of glutathione. To determine whether enhancing antioxidant buffer capacity of plants is sufficient to enhance germination in a manner similar to T22 treatment, glutathione $(\mathrm{GSH})$ was exogenously applied to germinating seed. GSH was added to germination media at a final concentration of $3 \mathrm{mM}$, according to Borsani and associates (12). Treatments included control; lowered water potential media of P1, P2, or P3 $(-0.1,-0.2$, or $-0.3 \mathrm{MPa}$, respectively $) \pm \mathrm{T} 22$ or $\pm \mathrm{GSH}$; and seed 
aged for 20 days \pm T22 or \pm GSH. Seed were incubated at $25 \pm$ $1{ }^{\circ} \mathrm{C}$ with $16 \mathrm{~h}$ of light. Germination was monitored and final germination percentage was determined 14 days later.

Statistical analysis. A factorial design was used for all of the experiments. Factors tested in each experiment were the main effects of T22 ( \pm ) and source of stress (i.e., aging, osmotic stress, salinity, chilling, or heat), and interactions between T22 and each stress factor. Each experiment consisted of four replications and was repeated twice. All data were analyzed by the analysis of variance using the JMP 7 for Windows (SAS) statistical package. Means were compared using a $t$ test at $\alpha=0.05$ to determine whether the imposed level of stress, T22, or T22-stress interaction significantly affected the speed of germination, percentage of germination, or root or shoot FW or DW. To compare the distribution of seedling sizes, the Shapiro-Wilk test of normality was used from JMP7.

To determine the $T_{50}$ values, a nonlinear logistic model was fitted to germination data. Several models were tested and the goodness of fit was compared and a logistic model with three predictors was selected to determine $\mathrm{T}_{50}$, as follows: $g=\theta_{1} /(1+$ $\left.\theta_{2} \times e^{\theta 3 \times t}\right)$, where $g$ is germination at time $t ; \theta_{1}, \theta_{2}$, and $\theta_{3}$ are parameters describing the germination curve; and $e=2.7182$.

TABLE 1. Effect of T22 on germination percentage and speed of germination $\left(\mathrm{T}_{50}\right)$ of unaged or aged seed of 'Jubilee' tomato ${ }^{\mathrm{X}}$

\begin{tabular}{lccccc}
\hline & \multicolumn{2}{c}{ Germination $(\%)$} & & \multicolumn{2}{c}{$\mathrm{T}_{50}(\mathrm{~h})^{\mathrm{z}}$} \\
\cline { 2 - 3 } \cline { 5 - 5 } Treatment $^{\mathrm{y}}$ & $-\mathrm{T} 22$ & $+\mathrm{T} 22$ & & $-\mathrm{T} 22$ & $+\mathrm{T} 22$ \\
\hline A0 & $94.5 \pm 0.73 \mathrm{a}$ & $94.5 \pm 0.65 \mathrm{a}$ & & $59.7 \pm 1.97 \mathrm{ab}$ & $56.6 \pm 0.89 \mathrm{a}$ \\
A10 & $90.3 \pm 0.76 \mathrm{a}$ & $91.1 \pm 0.85 \mathrm{a}$ & & $64.8 \pm 2.95 \mathrm{~b}$ & $57.6 \pm 1.03 \mathrm{a}$ \\
A20 & $86.6 \pm 0.88 \mathrm{~b}$ & $89.3 \pm 0.88 \mathrm{a}$ & & $70.0 \pm 1.85 \mathrm{c}$ & $63.1 \pm 1.19 \mathrm{~b}$ \\
\hline
\end{tabular}

${ }^{x}$ Seed were germinated in aseptic culture on blotter paper and were maintained at $25 \pm 1^{\circ} \mathrm{C}$ with $16 \mathrm{~h}$ of light. Each number is average of eight replications in two experiments \pm standard error of the mean. Averages followed by the same letter are not statistically different according to the Student's $t$ least significant difference test.

y A0, A10, or A20 stand for unaged seed or seed rapidly aged for 10 or 20 days, respectively.

${ }^{z}$ Time to germination of $50 \%$ of seed.
This model could be used to predict germination percentage at time $t$ or to predict the time $t$ when a specific germination percentage occurs. For instance, to determine $\mathrm{T}_{50}$, germination percentage $g$ was set as 50 and $t$ was calculated based on the $\theta_{1}, \theta_{2}$, and $\theta_{3}$ obtained from the model.

\section{RESULTS}

Effects of T22 treatment on germination and early seedling growth. The speed of germination and percentage of seed germination were measured, whereby germination percentage is commonly used as an indicator of seed viability. However, this value is insufficiently sensitive for detecting slow reduction in seed quality that affects seed performance under field conditions. Speed of germination, on the other hand, better reflects these changes in the vigor (22). T22 treatment increased the speed of germination (lower $\mathrm{T}_{50}$ values) in unaged and aged seed of Jubilee tomato $(P=0.0006)$. Although the effect of this treatment was greater in aged seed than in unaged seed, the interaction effect between aging and T22 treatment (aging-T22) was not statistically significant $(P=0.4436)$. The percentage of germination increased in response to T22 treatment in A20 seed but not in unaged seed $(P=0.0023)$ (Table 1$)$.

Radicle and hypocotyl length (growth) and FW of seedlings (biomass accumulation) produced from unaged seed of Jubilee tomato 2 weeks after planting in aseptic culture was not affected by T22 treatment $(P=0.3564)$ (Table 2$)$.

Seedling growth was compromised due to rapid aging in A10 and A20 compared with unaged seed $(P=0.0001)$ but T22 treatment partially restored growth $(P<0.0001$, using the Shapiro-Wilk's test), although not always to the level of unaged seed (Fig. 1). Seedlings produced from T22-treated aged seed had greater growth (hypocotyl length of both A10 and A20 and radicle length of A20) and biomass accumulation (shoot FW of A20 and root FW of both A10 and A20) (Table 2) than did seedlings from untreated seed.

Seedling emergence in soil infested with $P$. ultimum. Neither seed treatment nor Pythium spp. infestation of soil had an effect on speed of germination or percentage of seedlings emerging 1

TABLE 2. Effect of T22 on growth of 'Jubilee' tomato seedlings produced from unaged or aged seed ${ }^{y}$

\begin{tabular}{|c|c|c|c|c|c|c|c|c|}
\hline \multirow[b]{2}{*}{ Treatment $^{\mathrm{z}}$} & \multicolumn{2}{|c|}{ Shoot length $(\mathrm{cm})$} & \multicolumn{2}{|c|}{ Root length $(\mathrm{cm})$} & \multicolumn{2}{|c|}{ Shoot fresh weight (mg) } & \multicolumn{2}{|c|}{ Root fresh weight (mg) } \\
\hline & $-\mathrm{T} 22$ & $+\mathrm{T} 22$ & $-\mathrm{T} 22$ & $+\mathrm{T} 22$ & $-\mathrm{T} 22$ & $+\mathrm{T} 22$ & $-\mathrm{T} 22$ & $+\mathrm{T} 22$ \\
\hline A0 & $4.5 \pm 0.2 \mathrm{a}$ & $4.4 \pm 0.1 \mathrm{a}$ & $8.2 \pm 0.2 \mathrm{a}$ & $7.8 \pm 0.3 \mathrm{ab}$ & $31.6 \pm 0.8 \mathrm{a}$ & $31.5 \pm 0.6 \mathrm{a}$ & $10.4 \pm 0.2 \mathrm{a}$ & $10.1 \pm 0.2 \mathrm{a}$ \\
\hline
\end{tabular}

y Seed were planted in aseptic media $\left(0.8 \%\right.$ WA) and were harvested after 14 days of growth in $25 \pm 1{ }^{\circ} \mathrm{C}$ with $16 \mathrm{~h}$ of light. Averages followed by the same letter are not statistically different according to the Student's $t$ least significant difference test.

${ }^{\mathrm{z}} \mathrm{A} 0$, A10, or A20 stand for unaged seed or seed rapidly aged for 10 or 20 days, respectively.

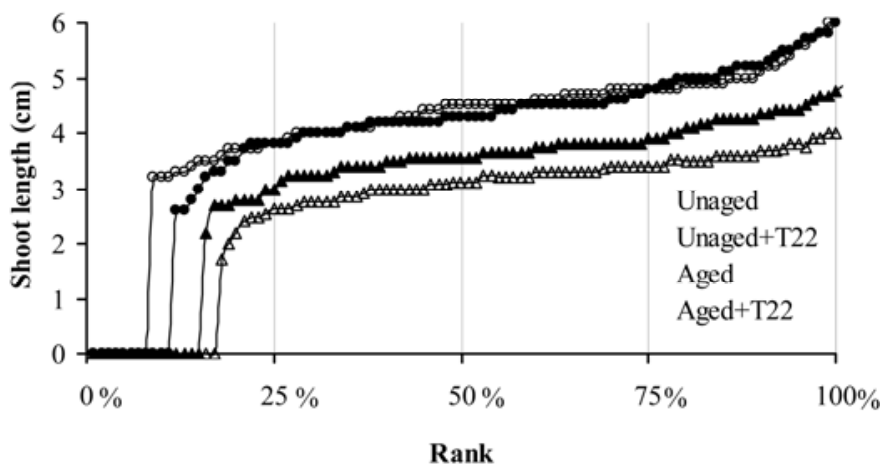

Fig. 1. Distribution of tomato shoot length as affected by rapid aging and T22 treatment; $\bigcirc$ and $\Delta$ show the shoot length for untreated unaged or 20-day-aged seed, respectively; and $\boldsymbol{-}$ and $\boldsymbol{\Delta}$ show the shoot length of seedlings produced from T22-treated unaged or 20-day-aged seed, respectively. Shoot length was measured 14 days after planting of seed in magenta boxes. Plants were maintained in growth chambers at $25 \pm 1{ }^{\circ} \mathrm{C}$. 
week after planting (data not shown). However, 15\% of seedlings from untreated seed were lost due to post-emergence damping off, whereas there was no seedling mortality in seedlings produced from T22-treated seed. Pythium infestation of soil reduced root dry mass significantly $(P<0.0001,1.14 \pm 0.17 \mathrm{~g} /$ plant in the control and $0.58 \pm 0.17 \mathrm{~g} / \mathrm{plant}$ in Pythium-infested soil) but shoot dry mass was not affected. The mass of roots from T22-treated seed was $46 \%$ higher than seedlings without the beneficial fungus.

Trichoderma spp. treatment enhanced germination and growth under abiotic stresses. Osmotic stress. To study the effect of seed treatment with T22 on germination of seed under osmotic stress, seed were planted in water agar plates with lowered water potential. Germination of seed was progressively reduced by lowering of the water potential of the germination media, and final germination, measured 14 days after the start of experiment, was severely affected by osmotic stress, especially at -0.2 and $-0.3 \mathrm{MPa}$ (Fig. 2). However, seed treatment with T22 enhanced speed of germination $(P<0.0001)$ and seed treated with T22 germinated faster and more uniformly compared with untreated seed at all water deficit levels (Fig. 2). Seedling growth was also improved by T22 treatment (Table 3).

Salinity. T22 treatment enhanced speed of germination (data not shown) at $\mathrm{S} 1$ and $\mathrm{S} 2$ and increased percentage of germination in S2 (Fig. 3). T22 treatment also partially restored the vigor of seedlings under different levels of salinity stress (Table 3 ).
Chilling and heat stress. Less than $5 \%$ of seeds incubated at $35^{\circ} \mathrm{C}$ for 3 days germinated during this treatment and no germination was observed in seeds imbibed for 1 to 3 days at $10^{\circ} \mathrm{C}$ or 1 day at $35^{\circ} \mathrm{C}$. After exposure to chilling or heat, imbibed seed were then returned to the germination chamber for germination at $25^{\circ} \mathrm{C}$. Both chilling and heat stresses reduced germination speed in seed compared with control seed (Fig. 4A and B). Longer exposure to low temperature ( 3 days) reduced germination speed more than 1 day of exposure but there was a significant reduction in vigor when seed were exposed to heat for 3 days compared with 1 day (Fig. 5). T22 enhanced speed of seed germination $(P=$ $0.0006)$ and treated seed germinated faster than untreated seed under all combinations of heating or chilling stress periods. There was not a significant interaction between T22 application and chilling or heat stresses. Although T22-treated seed germinated significantly faster than untreated seed, the final germination percentage was not significantly different.

T22 treatment reduces lipid peroxidation. Total lipid peroxides of tomato seedlings germinated under lowered water potentials or that of aged seed was compared between T22-treated or control seedlings. To compare the level of lipid peroxides in samples with similar physiological age, samples were harvested when $\approx 50 \%$ of seedlings in each treatment had radicles $\geq 3 \mathrm{~mm}$ (Table 4). T22 treatment and osmotic stress significantly affected lipid peroxide levels $(P=0.035$ and $P<0.0001$, respectively) but the effect of seed aging was not significant $(P=0.239)$. Lipid peroxide content

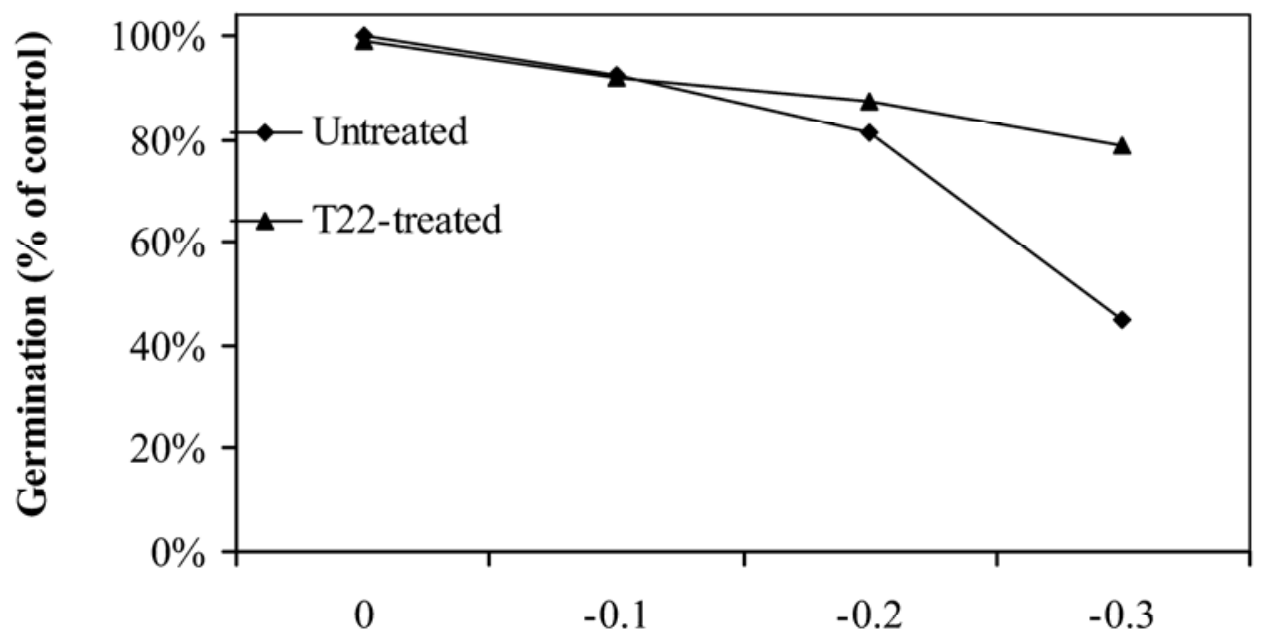

\section{Water Potential of media (MPa)}

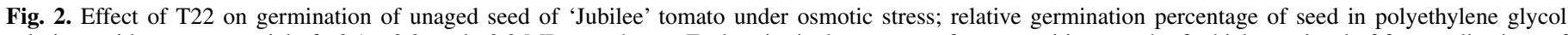

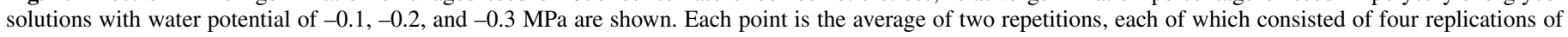
50 seeds.

TABLE 3. Effect of T22 on seedling growth under osmotic stress and salinity

\begin{tabular}{|c|c|c|c|c|}
\hline \multirow[b]{2}{*}{ Source of stress, level ${ }^{\mathrm{z}}$} & \multicolumn{2}{|c|}{ Shoot length $(\mathrm{cm})$} & \multicolumn{2}{|c|}{ Root length $(\mathrm{cm})$} \\
\hline & $-\mathrm{T} 22$ & $+\mathrm{T} 22$ & $-\mathrm{T} 22$ & $+\mathrm{T} 22$ \\
\hline Control & $4.29 \pm 0.16 \mathrm{a}$ & $4.12 \pm 0.10 \mathrm{a}$ & $7.92 \pm 0.20 \mathrm{a}$ & $7.58 \pm 0.16 \mathrm{a}$ \\
\hline \multicolumn{5}{|l|}{ Water potential } \\
\hline $\mathrm{P} 1$ & $3.59 \pm 0.17 \mathrm{abc}$ & $3.89 \pm 0.11 \mathrm{ab}$ & $7.10 \pm 0.22 \mathrm{ab}$ & $7.49 \pm 0.17 \mathrm{a}$ \\
\hline $\mathrm{P} 2$ & $2.91 \pm 0.13 \mathrm{c}$ & $3.65 \pm 0.21 \mathrm{ab}$ & $6.50 \pm 0.19 \mathrm{c}$ & $7.02 \pm 0.12 \mathrm{ab}$ \\
\hline P3 & $2.04 \pm 0.24 \mathrm{~d}$ & $3.09 \pm 0.18 b c$ & $5.17 \pm 0.26 \mathrm{~d}$ & $6.38 \pm 0.17 \mathrm{c}$ \\
\hline \multicolumn{5}{|l|}{ Salinity } \\
\hline $\mathrm{S} 1$ & $3.21 \pm 0.29 \mathrm{bc}$ & $3.62 \pm 0.15 \mathrm{ab}$ & $6.95 \pm 0.13 \mathrm{ab}$ & $7.54 \pm 0.11 \mathrm{a}$ \\
\hline $\mathrm{S} 2$ & $2.05 \pm 0.27 \mathrm{~d}$ & $2.99 \pm 0.23 \mathrm{c}$ & $5.26 \pm 0.24 \mathrm{~d}$ & $6.95 \pm 0.21 \mathrm{ab}$ \\
\hline $\mathrm{S} 3$ & $\ldots$ & $\ldots$ & $\ldots$ & $\ldots$ \\
\hline
\end{tabular}

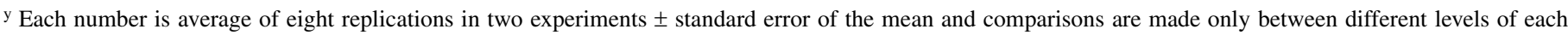
stress and control. Averages followed by the same letter are not statistically different according to the Student's $t$ least significant difference test.

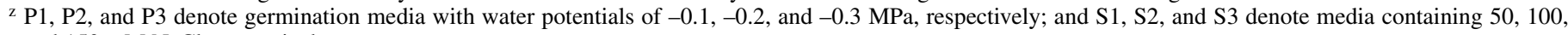
and $150 \mathrm{mM} \mathrm{NaCl}$, respectively. 
increased eightfold in seedlings grown at $-0.2 \mathrm{MPa}$ compared with control seedlings. Lipid peroxide content of T22-treated seedlings also increased with the reduction in water potential but, at $-0.2 \mathrm{MPa}$, concentration of lipid peroxides in T22-treated seedlings was significantly lower than that of untreated seedlings (Table 4).

Exogenous GSH application. Exogenous application of $3 \mathrm{mM}$ GSH counteracted the negative effect of osmotic stress and seed aging on germination of seed under lowered water potential. T22 treatment and GSH treatment increased seed germination by similar amounts (Fig. 5). Exogenous application of GSH gave a numerical increase in germination percentage of aged seeds but the level was not significant (data not shown).

\section{DISCUSSION}

A single treatment of seed or plants that could simultaneously confer resistance to biotic stresses (disease) and abiotic stresses would be of importance to agricultural plant production. This report demonstrates that seed treatments with $T$. harzianum are capable of alleviating abiotic and physiological stresses in seed and seedlings. Trichoderma spp. are among the most widely used organisms for biological disease control and for plant growth promotion $(30,35)$. This report also shows that they induce tolerance to abiotic stresses and indicate that there is an opportunity to improve plant agriculture by fully utilizing their capabilities.

A few recent reports demonstrated that these fungi alleviate abiotic stresses. Field data indicates that they may confer tolerance to drought stress at least in part through promotion of deeper root penetration into the soil profile (28). In a recent report, $T$. hamatum increased tolerance of cocoa plants to water deficit through increasing root growth that provided greater water resources to treated plants and delayed the onset of water deficit in these plants (6). In another report (69), squash plants treated with T22 or other beneficial microorganisms were more tolerant of salinity than untreated ones. These data, along with the frequent observation that the greatest advantage of Trichoderma treatments to plants occurs when they are under stress, gives credence to the concept that these beneficial fungi ameliorate both biotic and abiotic plant stresses.

However, there are almost no reports of the abilities of Trichoderma spp. to alleviate stresses that occur in the seed and early in germination. An exception was the report by Björkman and associates (11) that a seed treatment with $T$. harzianum could confer advantages to maize seed with poor vigor caused by genetic manipulations (early varieties of sweet corn with the $s h$ gene), increasing both vigor and germination. The present study examined effects of Trichoderma treat,emt of tomato seed on several physiological and abiotic stresses during imbibition and germination. All stresses examined were alleviated by T22 treatment, including osmotic and salinity stresses, changes in temperature, and loss of seed quality due to storage conditions that give rise to physiological intrinsic stress. This is of substantial importance to plant agriculture because yields and productivity of plants usually require high and uniform seed germination and strong seedling vigor.

Despite significant differences between these stresses, signaling pathways and cellular responses to them share common features $(1,6,13,16-19,43,47,52-54)$. Therefore, even though various stresses were alleviated by T22 treatment, there may be similar mechanisms induced by the fungus resulting in amelioration of all of the stresses applied. One such common mechanism could be the control of damage caused by the reactive oxygen species. These molecules that play a crucial signaling role during abiotic stresses at higher concentration cause cellular and molecular damages (46). Most ROS are unstable and are quickly converted to $\mathrm{H}_{2} \mathrm{O}_{2}$, which is either reduced to water during the ascorbateGSH cycle, converted to water and oxygen by catalase enzyme, or used as a substrate of peroxidase enzymes $(17,18,49)$. However, in the presence of transition metal ions, $\mathrm{H}_{2} \mathrm{O}_{2}$ is converted to hydroxyl radicals, which start chain reactions leading to the peroxidation of membrane lipids (5) that result in loss of membrane integrity and also damage to other macromolecules. Thus, measurement of lipid peroxide content serves as a reliable indicator of oxidative damage $(46,51)$ during abiotic stresses. We found an increase in level of lipid peroxide content in young seedlings under osmotic stress but T22-treated seedlings had significantly lower level of lipid peroxides. Seed aging results in lipid preoxidation (33), but in this study, although numerical increases in peroxide levels were detected and T22 reduced these, neither effect was statistically significant. Exogenous application of GSH was sufficient to enhance germination of seed under osmotic stress, an effect similar to that of T22 treatment. GSH can directly react with a range of ROS (50) and is involved in the ascorbateGSH cycle, during which $\mathrm{H}_{2} \mathrm{O}_{2}$ is reduced to water (49). It is also known to induce expression of $\mathrm{Cu} / \mathrm{Zn}$ superoxide dismutase (37),

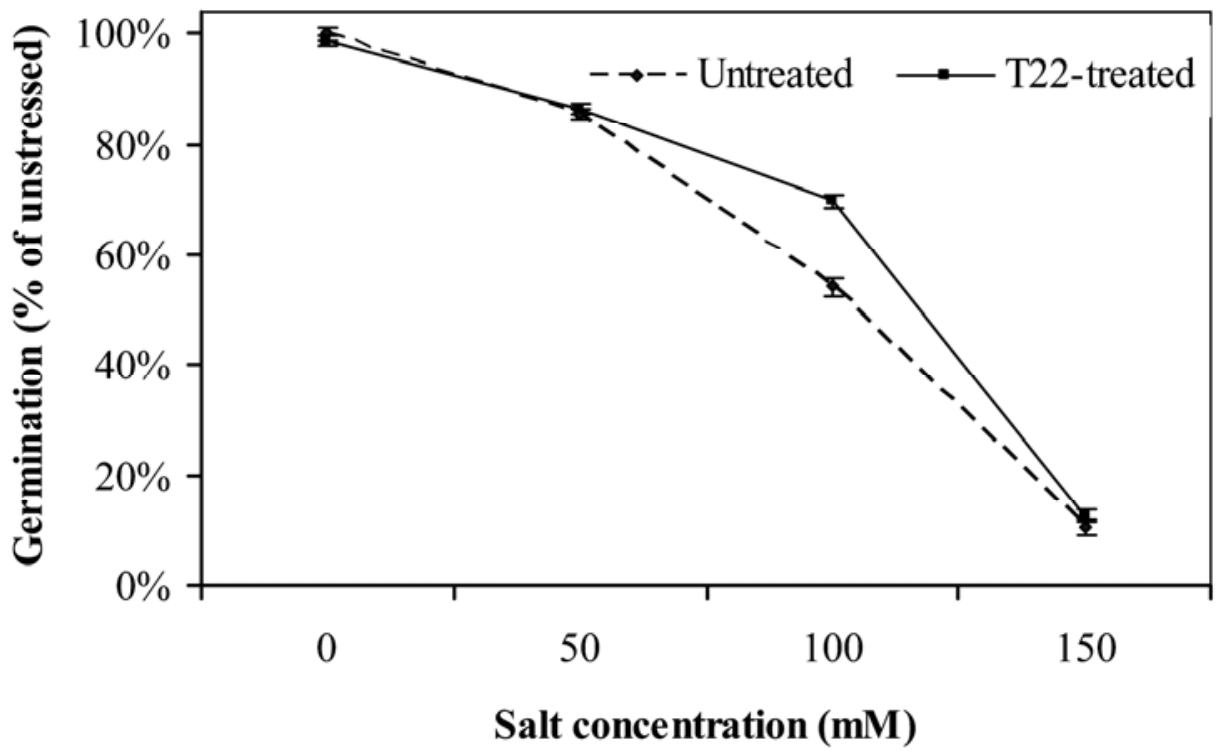

Fig. 3. Effect of $\mathrm{T} 22$ and salinity on germination of unaged seed of 'Jubilee' tomato; relative germination percentages of seed in media with 50, 100, and $150 \mathrm{M}$ $\mathrm{NaCl}$ are shown. Each point is the average of two repetitions, each of which consisted of four replications of 30 seeds. 


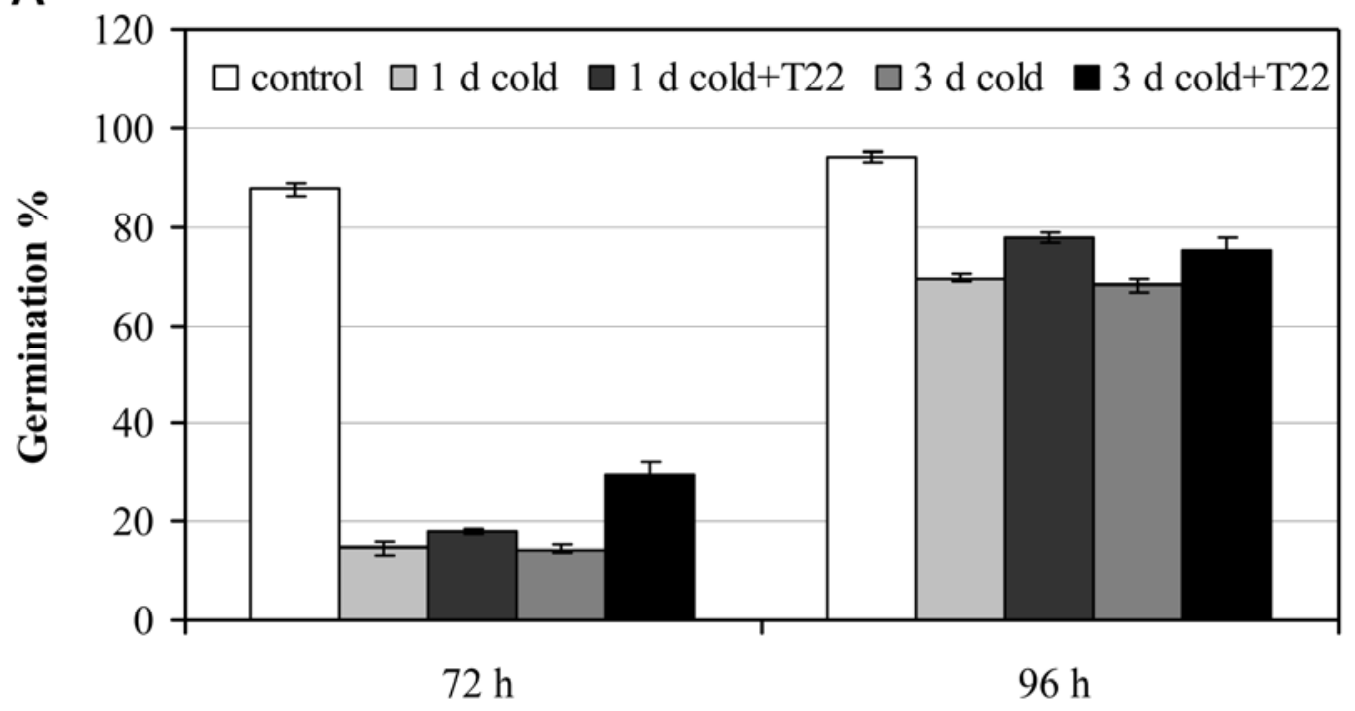

Time after imbibition (h)

B

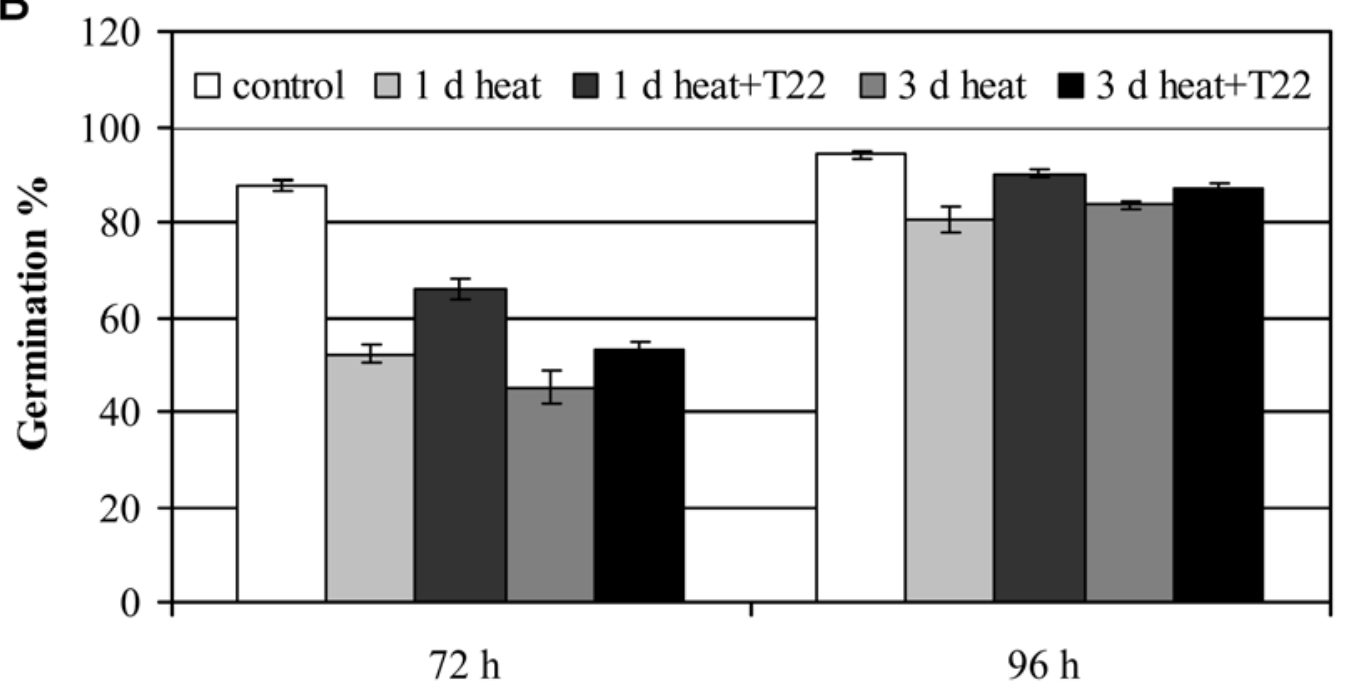

Time after imbibition (h)

Fig. 4. Effect of T22 on germination of 'Jubilee' tomato seed exposed to chilling or heat stress; seed were imbibed for $24 \mathrm{~h}$ at $25 \pm 1^{\circ} \mathrm{C}$ and then exposed to either A, $10^{\circ} \mathrm{C}$ for either 1 or 3 days or $\mathbf{B}, 35^{\circ} \mathrm{C}$ for 1 or 3 days. Striped columns relate to germination of untreated seed at 72 or $96 \mathrm{~h}$ after imbibition (excluding the period in which seed were incubated at either low or high temperatures) and solid column to that of T22-treated seed.

an important ROS scavenging enzyme. This evidence supports the model that T. harzianum strain T22 increases seedling vigor and ameliorates stress by inducing plant physiological protection against oxidative damage. Interestingly, an increase in the level of several families of protective proteins, including GSH-dependent enzymes such as glutathione reductase and glutathion $\mathrm{S}$ transferase, in Trichoderma-treated maize and other seedlings has been reported previously $(2,3,7,9,58)$. The mechanisms whereby Trichoderma spp. induce such changes are not known; however, enhanced ROS level could act as a signal to regulate expression of some of the related genes. A transient increase in intracellular ROS has been detected 5 to 10 min after treating soybean cell culture with culture filtrate of $T$. atroviride (48). Such signals, along with $\mathrm{Ca}^{++}$signaling (48), can induce plant ROS scavenging mechanisms (46). resulting in elevated protection against the oxidative damage.
A question that may arise is whether the fungi can tolerate and proliferate in conditions tested in this work. It is known that T22, unlike many naturally occurring and selected strains of Trichoderma $(31,67)$, is resistant to conditions resulting in oxidative damage such as application of fungicides that act by inducing lipid peroxidation (31) or application of paraquat at concentrations as high as $50 \mathrm{ppm}$ (F. Mastouri, unpublished data). In addition, fungal biomass, sporulation, or spore germination is not affected in media with water potentials as low as $-2.0 \mathrm{MPa}$ (41). Therefore, it is likely that the fungi can easily establish in suboptimal conditions such as those tested here. However, the results may not be extended to other selected or natural strains or other cultivars or plants species without further studies.

In addition to the induction of tolerance to abiotic stresses, Trichoderma spp. induce other changes in host plants, including induced systemic resistance and increased nitrogen use efficiency 


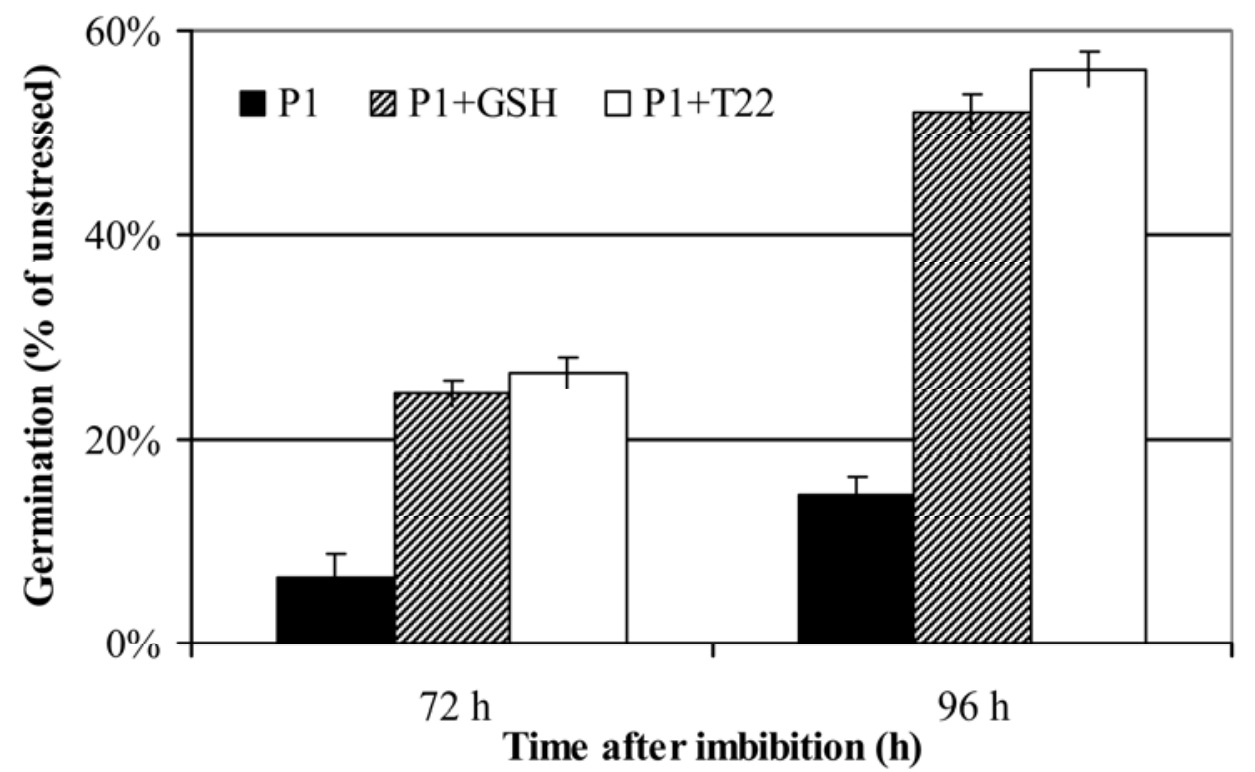

Fig. 5. Germination of tomato seed as affected by osmotic stress of media and treatment with glutathione (GSH) or T22. Relative percentages of germination at 72 and $96 \mathrm{~h}$ are shown. Each value is the average of two experiments, each with fours replicates. Vertical bars show standard error.

TABLE 4. Lipid peroxide content ( $\mu \mathrm{mol} \mathrm{g}^{-1}$ fresh weight) of tomato seedlings untreated or treated with $\mathrm{T} 22^{\mathrm{z}}$

\begin{tabular}{lccccc}
\hline & \multicolumn{2}{c}{$\begin{array}{c}\text { Harvest time } \\
(\text { day after planting })\end{array}$} & & \multicolumn{2}{c}{$\begin{array}{c}\text { Lipid peroxide } \\
\left(\mu \mathrm{mol} \mathrm{g}^{-1}\right)\end{array}$} \\
\cline { 2 - 3 } \cline { 5 - 6 } Water potential & $-\mathrm{T} 22$ & $+\mathrm{T} 22$ & & $-\mathrm{T} 22$ & \\
\hline Control & 5 & 5 & & $1.1 \pm 0.7 \mathrm{a}$ & $0.8 \pm 0.9 \mathrm{a}$ \\
P1 & 8 & 5 & & $3.1 \pm 1.0 \mathrm{~b}$ & $2.2 \pm 1.1 \mathrm{ab}$ \\
P2 & 10 & 8 & & $8.5 \pm 2.4 \mathrm{c}$ & $4.1 \pm 1.2 \mathrm{~b}$ \\
Control & 5 & 5 & & $1.0 \pm 0.4 \mathrm{c}$ & $0.8 \pm 0.5 \mathrm{c}$ \\
A20 & 7 & 5 & & $1.1 \pm 0.6 \mathrm{c}$ & $0.8 \pm 0.6 \mathrm{c}$ \\
\hline
\end{tabular}

${ }^{\mathrm{z}}$ Seed exposed to either physiological stress (rapid aging) or osmotic stress were germinated in two independent experiments and the lipid peroxide content of seedlings were measured when $50 \%$ of seedlings had radicles $\geq 3 \mathrm{~mm}$. Numbers are average of three replications \pm standard error. Comparisons were performed between different levels of each stress $\pm \mathrm{T} 22$ only and no comparison was done between lipid peroxide of aged seed or those germinated under osmotic stress. Averages followed by the same letter are not statistically different according to the Student's $t$ least significant difference test.

$(30,32,59)$. Similar benefits have been observed as a result of association of plants with other beneficial microorganisms, including plant-growth-promoting rhizobacteria (PGPR) and Piriformaspora indica fungi. Other free-living rhizosphere-competent fungi such as nonpathogenic Fusarium spp. and binucleate Rhizoctonia spp. (Ceratorhiza spp.) may also affect plants similarly. All of these organisms colonize plants internally $(10,15$, $21,26,40,42,44,55,63,64,68,70)$ and many of them exhibit the same ranges of activities as T22, as recently summarized $(27,59)$. It is possible that there are only a few mechanisms whereby these broad-spectrum activities occur. Systemic disease resistance probably occurs primarily by activation of the induced systemic resistance pathway in plants (61). However, the amelioration of oxidative damage may also be important during plant-pathogen interactions $(64,65)$. Evidence presented in this article indicates that abiotic stress resistance, at least for osmotic stress, is alleviated through amelioration of damage caused by ROS, similar to what was previously observed in plants treated with $P$. indica $(10,64)$ or PGPR $(20,24)$. These effects, along with increased root and shoot growth, all are energy requiring, suggesting that both photosynthesis levels and efficiency are increased in the presence of Trichoderma spp. and similar endophytic fungi, as suggested by proteomic studies $(57,58)$ and our ongoing work. Thus, there may be only a few basic mechanisms for a wide range of benefits in plant production. These results suggest that Trichoderma spp. and some other endophytic microbes may alleviate a range of biotic, abiotic, and even physiological stresses. All these benefits, together with increasing nitrogen use efficiency $(32,56)$ indicate substantial commercial potential beyond current uses of these organisms.

\section{ACKNOWLEDGMENTS}

This work is part of the Ph.D. thesis of F. Mastouri, who was financially supported by an assistantship from the Department of Horticultural Science, NYSAES, Cornell University. We thank A. Taylor for constructive discussions and A. Brooks and G. Knapton from G. E. Harman's laboratory for help that facilitated this work.

\section{LITERATURE CITED}

1. AbuQamar, S., Luo, H., Laluk, K., Mickelbart, M. V., and Mengiste, T. 2009. Crosstalk between biotic and abiotic stress responses in tomato is mediated by the AIM1 transcription factor. Plant J. 58:347-360.

2. Alfano, G., Bos, J., Cakir, C., Horst, L., Ivey, M., Madden, L. V., Kamoun, S., and Hoitink, H. 2006. Modulation of gene expression in tomato by Trichoderma hamatum 382. (Abstr.) Phytopathology 96:S4.

3. Alfano, G., Ivey, M. L. L., Cakir, C., Bos, J. I. B., Miller, S. A., Madden, L. V., Kamoun, S., and Hoitink, H. A. J. 2007. Systemic modulation of gene expression in tomato by Trichoderma hamatum 382. Phytopathology 97:429-437.

4. AOSA. 2009. Seedling evaluation. Pages 110-115 in: Rules for Testing Seeds. AOSA, ed. AOSA, Washington, DC.

5. Aust, S. D., Morehouse, L. A., and Thomas, C. 1985. Role of metals in oxygen radical reactions. J. Free Radic. Biol. Med. 1:3-26.

6. Bae, H., Sicher, R. C., Kim, M. S., Kim, S.-H., Strem, M. D., Melnick, R. L., and Bailey, B. A. 2009. The beneficial endophyte Trichoderma hamatum isolate DIS $219 \mathrm{~b}$ promotes growth and delays the onset of the drought response in Theobroma cacao. J. Exp. Bot. 60:3279-3295.

7. Bae, H., Sicher, R. C., Kim, S.-H., Kim, M. S., Strem, M. D., and Bailey, B. A. 2006. The response of Theobroma cacao (cacao) to abiotic and biotic stresses and the role of beneficial endophytes. Plant Biol. 2006:186.

8. Bailey, B., Bae, H., Strem, M., Samuels, G., Evans, H., Thomas, S., and Holmes, K. 2005. Molecular responses resulting from the endophytic association between Trichoderma species and cocoa (Theobroma cacao). (Abstr.) Phytopathology 95:S5.

9. Bailey, B. A., Bae, H., Strem, M. D., Roberts, D. P., Thomas, S. E., Crozier, J., Samuels, G. J., Choi, I.-Y., and Holmes, K. A. 2006. Fungal and plant gene expression during the colonization of cacao seedlings by endophytic isolates of four Trichoderma species. Planta 224:1449-1464.

10. Baltruschat, H., Fodor, J., Harrach, B. D., Niemczyk, E., Barna, B., 
Gullner, G., Janeczko, A., Kogel, K.-H., Schaefer, P., Schwarczinger, I., Zuccaro, A., and Skoczowski, A. 2008. Salt tolerance of barley induced by the root endophyte Piriformospora indica is associated with a strong increase in antioxidants. New Phytol. 180:501-510.

11. Bjorkman, T., Blanchard, L. M., and Harman, G. E. 1998. Growth enhancement of shrunken-2 (sh2) sweet corn by Trichoderma harzianum 1295-22: Effect of environmental stress. J. Am. Soc. Hortic. Sci. 123:3540.

12. Borsani, O., Valpuesta, V., and Botella, M. A. 2001. Evidence for a role of salicylic acid in the oxidative damage generated by $\mathrm{NaCl}$ and osmotic stress in Arabidopsis seedlings. Plant Physiol. 126:1024-1030.

13. Bowler, C., and Fluhr, R. 2000. The role of calcium and activated oxygens as signals for controlling cross-tolerance. Trends Plant Sci. 5:241-246.

14. Bradford, K. J. 1995. Population-based models of seed viability loss during storage: what's the use? Hortscience 30:910.

15. Cardoso, J. E., and Echandi, E. 1987. Biological control of Rhizoctonia root rot of snap bean with binucleate Rhizoctonia-like fungi. Plant Dis. 71:167-170.

16. Chinnusamy, V., Schumaker, K., and Zhu, J.-K. 2004. Molecular genetic perspectives on cross-talk and specificity in abiotic stress signaling in plants. J. Exp. Bot. 55:225-236.

17. Foyer, C. H., Kiddle, G., Antoniw, J., Bernard, S., Verrier, P. J., Pastori, G. M., and Noctor, G. 2003. The role of antioxidant-mediated signal transduction during stress. Mol. Cell. Proteomics 2:682.

18. Foyer, C. H., Kiddle, G., Pastori, G. M., Antoniw, J., Verrier, P. J., and Noctor, G. D. 2003. Ascorbate contents modulate defence processes and plant development. Plant Biol. 2003:56.

19. Foyer, C. H., Trebst, A., and Noctor, G. 2006. Photoprotection, photoinhibition, gene regulation and environment. In: Signaling and Integration of Defense Functions of Tocopherol, Ascorbate and Glutathione. Adv. Photosynth. Respir. 21:241-268.

20. Gamalero, G., Erta, G., and Glick, B. R. 2009. The Use of Microorganisms to Facilitate the Growth of Plants in Saline Soils. Springer-Verlag, Heidelberg, Germany.

21. Gronberg, H., Kaparakis, G., and Sen, R. 2006. Binucleate Rhizoctonia (Ceratorhiza spp.) as non-mycorrhizal endophytes alter Pinus sylvestris L. seedling root architecture and affect growth of rooted cuttings. Scand. J. For. Res. 21:450-457.

22. Hacisalihoglu, G., Taylor, A. G., Paine, D. H., Hilderbrand, M. B., and Khan, A. A. 1999. Embryo elongation and germination rates as sensitive indicators of lettuce seed quality: priming and aging studies. Hortscience 34:1240-1243

23. Hadar, Y., Harman, G. E., and Taylor, A. G. 1984. Evaluation of Trichoderma koningii and Trichoderma harzianum from New York USA soils for biological control of seed rot caused by Pythium spp. Phytopathology 74:106-110.

24. Han, H. S., and Lee, K. D. 2005. Plant growth promoting rhizobacteria effect on antioxidant status, photosynthesis, mineral uptake and growth of lettuce under soil salinity. Res. J. Agric. Biol. Sci. 1:210-215.

25. Hara, A., and Radin, N. S. 1978. Lipid extraction of tissues with a low toxicity solvent. Anal. Biochem. 90:420-426.

26. Harman, G., Bjorkman, T., Ondik, K. L., and Shoresh, M. 2008. Changing paradigms on the mode of action and uses of Trichoderma spp. for biocontrol. Outlooks Pest Manage. 19:24-29.

27. Harman, G., Obergon, M. A., Samuels, G. J., and Lorito, M. 2010. Changing models of biocontrol in the developing and developed world. Plant Dis. 94:928-939.

28. Harman, G. E. 2000. Myths and dogmas of biocontrol: changes in perceptions derived from research on Trichoderma harzianum T-22. Plant Dis. 84:377-393.

29. Harman, G. E. 2006. Overview of mechanisms and uses of Trichoderma spp. Phytopathology 96:190-194.

30. Harman, G. E., Howell, C. R., Viterbo, A., Chet, I., and Lorito, M. 2004. Trichoderma species-opportunistic, avirulent plant symbionts. Nat. Rev. Microbiol. 2:43-56.

31. Harman, G. E., Latorre, B., Agosin, E., San Martin, R., Riegel, D. G., Nielsen, P. A., Tronsmo, A., and Pearson, R. C. 1996. Biological and integrated control of Botrytis bunch rot of grape using Trichoderma spp. Biol. Control 7:259-266.

32. Harman, G. E., and Mastouri, F. 2009. Enhanced nitrogen use efficiency in wheat using Trichoderma seed inoculants. Presented at IS-MPMI 2009 XIV Congress, Quebec, Canada.

33. Harman, G. E., and Mattick, L. R. 1976. Association of lipid oxidation with seed aging and death. Nature 260:323-324.

34. Harman, G. E., Petzoldt, R., Comis, A., and Chen, J. 2004. Interactions between Trichoderma harzianum strain T22 and maize inbred line Mo17 and effects of these interactions on diseases caused by Pythium ultimum and Colletotrichum graminicola. Phytopathology 94:147-153.

35. Harman, G. E., and Shoresh, M. 2007. The mechanisms and applications of symbiotic opportunistic plant symbionts. Pages 131-155 in: Novel
Biotechnologies for Biocontrol Agent Enhancement and Management. M. Vurro and J. Gressel, eds. Springer, Amsterdam.

36. Harman, G. E., Taylor, A. G., and Stasz, T. E. 1989. Combined effective strains of Trichoderma harzianum and solid matrix priming to improve biological seed treatments. Plant Dis. 73:631-637.

37. Herouart, D., Van Montagu, M., and Inze, D. 1993. Redox-activated expression of the cytosolic copper/zinc superoxide dismutase gene in Nicotiana. Proc. Natl. Acad. Sci. USA 90:3108-3112.

38. Howell, C. R. 2003. Mechanisms employed by Trichoderma species in the biological control of plant diseases: the history and evolution of current concepts. Plant Dis. 87:4-10.

39. Howell, C. R. 2006. Understanding the mechanisms employed by Trichoderma virens to effect biological control of cotton diseases. Phytopathology 96:178-180.

40. Jaroszuk-Scisel, J., Kurek, E., Winiarczyk, K., Baturo, A., and Lukanowski, A. 2008. Colonization of root tissues and protection against Fusarium wilt of rye (Secale cereale) by nonpathogenic rhizosphere strains of Fusarium culmorum. Biol. Control 45:297-307.

41. Jin, X., Harman, G. E., and Taylor, A. G. 1991. Conidial biomass and desiccation tolerance of Trichoderma harzianum produced at different medium water potentials. Biol. Control 237-243.

42. Kloepper, J. W., Ryu, C.-M., and Zhang, S. 2004. Induced systemic resistance and promotion of plant growth by Bacillus spp. Phytopathology 94:1259-1266

43. Knight, H., and Knight, M. R. 2001. Abiotic stress signalling pathways: specificity and cross-talk. Trends Plant Sci. 6:262-267.

44. Kumar, M., Yadav, V., Tuteja, N., and Johri, A. K. 2009. Antioxidant enzyme activities in maize plants colonized with Piriformospora indica. Microbiology (Read.) 155:780-790.

45. Mastouri, F., and Harman, G. E. 2009. Beneficial microorganism Trichoderma harzianum induces tolerance to multiple environmental and physiological stresses during germination in seeds and seedlings. In: ISMPMI 2009 XIV Congress, Quebec, Canada

46. Mittler, R. 2002. Oxidative stress, antioxidants and stress tolerance. Trends Plant Sci. 7:405-410.

47. Moon, H., Lee, B., Choi, G., Shin, D., Prasad, D. T., Lee, O., Kwak, S.-S., Kim, D. H., Nam, J., Bahk, J., Hong, J. C., Lee, S. Y., Cho, M. J., Lim, C. O., and Yun, D.-J. 2003. NDP kinase 2 interacts with two oxidative stressactivated MAPKs to regulate cellular redox state and enhances multiple stress tolerance in transgenic plants. Proc. Natl. Acad. Sci. USA 100:358363.

48. Navazio, L., Baldan, B., Moscatiello, R., Zuppini, A., Woo, S. L., Mariani, P., and Lorito, M. 2007. Calcium-mediated perception and defense responses activated in plant cells by metabolite mixtures secreted by the biocontrol fungus Trichoderma atroviride. BMC Plant Biol. 7:4149.

49. Noctor, G., and Foyer, C. H. 1998. Ascorbate and glutathione: keeping active oxygen under control. Pages 249-279 in: Annu. Rev. Plant Physiol. Plant Mol. Biol. R. L. Jones, C. R. Somerville, and V. Walbot, eds. Annual Reviews, Inc., United States.

50. Noctor, G., Gomez, L., Vanacker, H., and Foyer, C. H. 2002. Interactions between biosynthesis, compartmentation and transport in the control of glutathione homeostasis and signalling. J. Exp. Bot. 53:1283-1304.

51. Orthen, B., Popp, M., and Smirnoff, N. 1993. Hydroxyl radical scavenging properties of cyclitols. Proc. R. Soc. Edinb. B 102:269-272.

52. Pastori, G. M., and Foyer, C. H. 2002. Common components, networks, and pathways of cross-tolerance to stress. The central role of "redox" and abscisic acid-mediated controls. Plant Physiol. 129:460-468.

53. Sabehat, A., Lurie, S., and Weiss, D. 1998. Expression of small heatshock proteins at low temperatures: a possible role in protecting against chilling injuries. Plant Physiol. 117:651-658.

54. Sabehat, A., Weiss, D., and Lurie, S. 1998. Heat-shock proteins and crosstolerance in plants. Physiol. Plant. 103:437-441.

55. Sen, R., Hietala, A. M., and Zelmer, C. D. 1999. Common anastomosis and internal transcribed spacer RFLP groupings in binucleate Rhizoctonia isolates representing root endophytes of Pinus sylvestris, Ceratorhiza spp. from orchid mycorrhizas and a phytopathogenic anastomosis group. New Phytol. 144:331-341

56. Sherameti, I., Shahollari, B., Venus, Y., Altschmied, L., Varma, A., and Oelmueller, R. 2005. The endophytic fungus Piriformospora indica stimulates the expression of nitrate reductase and the starch-degrading enzyme glucan-water dikinase in tobacco and Arabidopsis roots through a homeodomain transcription factor that binds to a conserved motif in their promoters. J. Biol. Chem. 280:26241-26247.

57. Shoresh, M., and Harman, G. E. 2008. Genome-wide identification, expression and chromosomal location of the genes encoding chitinolytic enzymes in Zea mays. Mol. Genet. Genomics 280:173-185.

58. Shoresh, M., and Harman, G. E. 2008. The molecular basis of shoot responses of maize seedlings to Trichoderma harzianum T22 inoculation of the root: a proteomic approach. Plant Physiol. 147:2147-2163. 
59. Shoresh, M., Mastouri, F., and Harman, G. 2010. Induced systemic resistance and plant responses to fungal biocontrol agents. Annu. Rev. Phytopathol. 48:21-43.

60. Shoresh, M., Viterbo, A., and Chet, I. 2004. Trichoderma asperellum and plant induced resistance. Acta Physiol. Plant. 26:123-124.

61. Shoresh, M., Yedidia, I., and Chet, I. 2005. Involvement of jasmonic acid/ethylene signaling pathway in the systemic resistance induced in cucumber by Trichoderma asperellum T203. Phytopathology 95:76-84.

62. Taylor, A. G., Hadar, Y., Norton, J. M., Khan, A. A., and Harman, G. E. 1985. Influence of presowing seed treatments of table beets Beta vulgaris cultivar Ruby-Queen on the susceptibility to damping-off caused by Pythium. J. Am. Soc. Horticult. Sci. 110:516-519.

63. Varma, A., Verma, S., Sudha, Sahay, N., Buetehorn, B., and Franken, P. 1999. Piriformospora indica, a cultivable plant-growth-promoting root endophyte. Appl. Environ. Microbiol. 65:2741-2744.

64. Waller, F., Achatz, B., Baltruschat, H., Fodor, J., Becker, K., Fischer, M., Heier, T., Hueckelhoven, R., Neumann, C., von Wettstein, D., Franken, P., and Kogel, K.-H. 2005. The endophytic fungus Piriformospora indica reprograms barley to salt-stress tolerance, disease resistance, and higher yield. Proc. Natl. Acad. Sci. USA 102:13386-13391.

65. Waller, F., Molitor, A., Pfiffi, S., Achatz, B., and Kogel, K. 2008. The root endophytic fungus Piriformospora indica accelerates host plant development and primes plants for disease resistance. (Abstr.) Phytopathology 98:S164.

66. Weindling R. 1932. Trichoderma lignorum as a parasite of other soil fungi. Phytopathology 22:837-845.

67. Wilkinson, V., and Lucas, R. L. Effects of herbicides on the growth of soil fungi. New Phytol. 68:709-719.

68. Yedidia, I., Benhamou, N., and Chet, I. 1999. Induction of defense responses in cucumber plants (Cucumis sativus L.) by the biocontrol agent Trichoderma harzianum. Appl. Environ. Microbiol. 65:1061-1070.

69. Yildirim, E., Taylor, A. G., and Spittler, T. D. 2006. Ameliorative effects of biological treatments on growth of squash plants under salt stress. Sci. Hortic. (Amst.) 111:1-6.

70. Zohar-Perez, C., Chet, I., and Nussinovitch, A. 2004. Unexpected distribution of immobilized microorganisms within alginate beads. Biotechnol. Bioeng. 88:671-674. 